\title{
Kaj Ahlsved
}

\section{"DET ÄR HEMMAPLANSFAVÖR!" STRUKTURERNA I TRE SPORTERS LJUDLANDSKAP STUDERADE UR ETT HI-FI/LO-FI-PERSPEKTIV}

\begin{abstract}
Sotkamon Jymys spelare springer ut på Saarikenttä för uppvärmning. Det är 70 minuter till matchstarten för Superpesis ${ }^{1}$-final nummer två. Sotkamospelarna hälsar på sina tillresta supportrar och tas emot med jubelrop. Vimpelin² Vetos supportrar buar lite grann. Kujala som ansvarar för musiken på Vimpelin Vetos matcher låter skivan Iskelmägaala $2008^{3}$ rulla på. Ett par minuter senare kommer Vimpelin Vetos spelare ut på. De tas emot med jubel av hemmapubliken. Kujala byter genast till hemmalagets uppvärmningsskiva och klickar fram till den andra låten på CD:n, Tämän kylän poikii av det finska popbandet Pariisin Kevät." (Ahlsved 2012c.)
\end{abstract}

Det finns mycket musik som omger oss i vår vardag, musik som bara finns där utan att vi har bett om att få lyssna på den. Denna allestädes närvarande musik (Kassabian 1999: 113-123) omgärdar oss på restauranger, caféer, butiker, i filmer men också på idrottsarenor. Användning av musik har även blivit en självklarhet

\footnotetext{
I Superpesis är den högsta serienivån i boboll i Finland.

2 Jag kommer jag att skriva Vimpelin Veto eller Vimpeli när jag i denna text syftar på bobollslaget som spelar i herrarnas Superpesis. Eftersom byn Vimpeli har ett svenskt ortsnamn kommer jag att skriva Vindala när jag syftar på samhället.

3 http: / / www.fono.fi / Dokumentti.aspx?culture=fi\&ID=6foe $4 a c_{4}-a_{5} f_{2}-43 f e-888 c-d 1185 f(5804 e$
} 
i sportindustrin, vilket har resulterat i att det i dag anordnas få evenemang utan musik, trots att musik inte behövs för den idrottsliga prestationen. Idrottsarenornas ljudlandskap associeras ofta med läktarsång, inte minst i fotboll (se Tuovinen 2007, Kytö 2011), men det finns också läktarkulturer där sportupplevelsen förknippas med mekanisk musik. Även om musiken, både i form av läktarsång och mekanisk musik, är så central i dagens sportindustri diskuteras ljudmiljön och dess konsekvenser sällan.

I denna artikel är jag främst intresserad av sportljudlandskapet som en helhet i vilken utövarnas och publikens, men också arrangörens ljud utgör en viktig del av sportupplevelsen. I det här avseendet ser jag likt Schafer (1994/[1977]) och Truax (1984) ett ljudlandskap som en abstrakt avgränsad konstruktion som kan studeras. Barry Truax, som har forskat i akustisk kommunikation, anser att lyssnaren alltid är närvarande i ett ljudlandskap och bidrar till det med sina ljud (Truax 1984: 9-10). När systemet är välbalanserat (hi-fi) utbyts mycket information mellan elementen ljud, lyssnare och miljö. I en lo-fi miljö går det däremot mycket information till spillo. Schafer har konstaterat att den elektroniska revolutionen medförde att man kunde paketera och förvara ljud och att man även kunde separera ljud från deras ursprungliga kontext, något som ledde till att världen började övergå till lo-fi ljudmiljöer. Schafer använder lo-fi som ett begrepp för miljöer där ljud överlappar varandra och mängden akustisk information gör att ljuden inte kan urskiljas klart. Urbana stadsmiljöer är lo-fi medan rurala ljudmiljöer är hi-fi eftersom man där tydligt kan urskilja ljud (Schafer 1994/[1977]: 88-89, 272).

Utgående från Schafers och Truax teorier kring begreppen lo-fi och hi-fi kommer jag att analysera tre olika sporters ljudlandskap. Mitt syfte är att utforska ljudlandskapens strukturer ur ett lo-fi/hi-fi perspektiv och belysa ljudets betydelse för helhetsupplevelsen av sportevenemanget. Enligt Truax (1984) skapas ljudlandskap av de människor som vistas i det och därför är det viktigt att studera de ljud som i ett sportsammanhang produceras av elementen utövare (idrottsmännen), publik och arrangör. Jag strävar efter att ur ett arrangörsperspektiv studera balansen mellan de olika elementen och diskutera hur arrangören med eller utan hjälp av mekanisk musik försöker skapa ett ljudlandskap där publikens aktiva deltagande möter arrangörens förväntningar. Jag kommer alltså att studera hur arrangören genom medvetna val försöker förändra balansen i ljudlandskapet i syfte att förbättra stämningen under sportevenemanget, och vilka konsekvenser detta val kan ha ur ett 
helhetsperspektiv. Jag kommer att lyfta fram hur traditioner styr arrangörernas val samt hur valen påverkas av regler och av sportens rytm och oförutsägbara natur.

Genom fältarbete och observationer på idrottsevenemang har jag identifierat hur dessa tre element (utövare, publik, arrangör) producerar ljud som utgör en viktig del av sportupplevelsen. Det tre sporter jag studerar, boboll, fotboll och ishockey, har alla en egen ljudkultur som bäst kan studeras på en lokal nivå. Därför har jag valt att göra fältarbete på FF Jaros (fotboll), Vimpelin Vetos (boboll) och HC TPS (ishockey) hemmamatcher. De utvalda sporterna representerar de tre största bollsporterna i Finland. Mitt material är insamlat genom fältarbete på lagens hemmamatcher: FF Jaros fotbollsmatcher i Veikkausliiga ${ }^{4}$ (FF Jaro-FC Lahti 7.10.2012), Vimpelin Vetos bobollsmatcher i Superpesis (Vimpeli-Kitee 11.8.2012, Vimpeli-Joensuu 21.8.2012, Vimpeli-Sotkamo 2.9.2012) samt HC тPS ishockeymatcher i FM-ligan ${ }^{5}$ (TPS-HPK 13.9.2012., TPS-Ilves 25.10.2012, TPS-Ilves 8.1.2013). Eftersom föreningarnas, alltså arrangörernas, praxis att använda inspelad musik är resultatet av traditioner och bestämmelser från respektive liga har jag även intervjuat och korresponderat med nyckelpersoner inom de olika ligorna och deras centralorganisationer. Dessa kan alltså också föreslås ingå i arrangörsbegreppet. Jag har också kompletterat mitt forskningsmaterial med en stor mängd fältarbete på andra matcher, både på plats och via Tv. Den viktigaste källan har varit att uppleva sporterna på plats och där har jag haft hjälp av erfarenheter från min avhandling pro gradu om ishockeymusik (Åbo Akademi, musikvetenskap 2008) samt av min personliga relation till $\mathrm{FF}$ Jaro som inleddes redan i slutet av 1980-talet. Jag har alltså inte bara suttit på läktarplats utan också följt med bakom kulisserna, avmystifierat sporten och observerat hur de olika lagen arbetar med sin ljudmiljö i realtid under matchens gång.

Jag kommer inledningsvis att gå närmare in på begreppet ljudlandskap och hur jag använder det i detta sammanhang. Vidare kommer jag att diskutera begreppen hi-fi och lo-fi och tillämpa dem på miljöer med främst utövar- och publikljud samt miljöer där mekanisk musik men också andra elektroakustiskt förstärkta ljudhändelser (sound events, Schafer 1994/[1977]; 274) förekommer i större utsträckning. Utgående från Schafers teorier (1994/[1977]) kan man konstatera att HC TPS ishockeyevenemang är en schizofon miljö. Jag kommer att tillämpa begreppet schizofoni

4 Veikkausliiga är den högsta fotbollsserien för herrar i Finland.

5 FM-ligan, på finska SM-liiga, är den högsta ishockeyserien för herrar i Finland. 
(schizophonia Schafer 1994/[1977]; 273) på mitt material och diskutera hur individens ljudlandskapskompetens spelar en viktig roll för att skapa sammanhang i lofi ljudmiljöer. På lokalnivå och en abstrakt metanivå finns det olika uppfattningar om hur sporten ska klinga och detta skapar vissa förväntningar på evenemangen. Det finns olika traditioner för musikanvändning inom de olika sporterna men man vill framförallt undvika tystnad. Eftersom det inte är tillåtet att spela musik när spelet är igång är standardiserade avbrott (exempelvis periodpauser), men även oförutsedda uppehåll (inkast, hörnor, utvisningar) grundförutsättningar för att man ska kunna förändra ljudlandskapet med musik. När man medvetet förändrar ett ljudlandskap är det en form av akustisk design (acoustic design, Schafer 1994/ [1977]: 271) där man samtidigt strävar efter att förändra beteendet hos de som vistas i ljudlandskapet. Inom ljudlandskapsforskningen har man myntat begreppet akustisk ekologi som syftar på studiet av balanserna i ljudlandskap (se t.ex. Wrightson 2000: 10-13). Jag ska avslutningsvis diskutera några konkreta exempel på hur man kan förändra balansen i ljudlandskapet.

\section{Ljudlandskap i sportsammanhang}

Jag kommer att använda begreppet ljudlandskap för att definiera den ljudmiljö jag undersöker. Ljudlandskapsforskningens fader R. Murray Schafer definierar ett ljudlandskap (soundscape) som en ljudmiljö, eller tekniskt sett även en avgränsad del av en ljudmiljö, som kan studeras. Med termen syftar han på verkliga landskap, men också abstrakta konstruktioner (Schafer 1994/[1977]: 274-275). Barry Truax (1984: 9-10) konstaterar att "ljudmiljön är summan av all ljudenergi i vilken kontext som helst, men vi använder begreppet 'ljudlandskap' för att understryka hur miljön förstås av de människor som vistas i den - de människor som skapar det". Ljudlandskapet formas alltså av de människor som vistas i ljudlandskapet. Det är med andra ord när matchen går av stapeln som ljudlandskapet formas och kan studeras. Boboll och fotboll spelas, i de fall jag undersöker, utomhus, vilket givetvis ger ljudlandskapet andra särdrag. Ljud från samhället runtomkring spelplatsen blir en del av sportens ljudlandskap och även självklarheter som att man i boboll och fotboll är utsatt för väder och vind kan bidra med nya element. Vimpelin Vetos spelplan Saarikenttä ligger mitt i byn, bredvid kyrkan, vilket gjorde 
att kyrkklockans helgmålsringning, som råkade sammanfalla med en just avslutad förlustmatch, blev en ödesmättad kommentar till händelserna på spelplanen (Ahlsved 2012a). Som abstrakta konstruktioner går mindre och större akustiska samhällen (acoustic communities) in i varandra. (se Järviluoma et al. 2009)

Ljudlandskapet på ett idrottsevenemang kan tolkas som ett akustiskt samhälle. Enligt Truax behöver ett akustiskt samhälle inte avgränsas till mängden människor det omfattar utan kan tolkas som ett system inom vilket akustisk information utbyts (Truax 1984: 58). Domarnas signaler, både auditiva och visuella, är bara en del av det kodsystem som reglerar det akustiska samhället. Professionella idrottsevenemang bygger på idén att det finns en publik som vill ta del av matchupplevelsen och det är människorna på plats som skapar ljudlandskapet. Taktiska rop, verbala utbrott från spelare och tränare, men också de ljud som uppstår som ett resultat av den sportsliga prestationen skapar sportens ljudlandskap och blir samtidigt en viktig del av upplevelsen.

De ljud som är ett resultat av genomförandet av den sportsliga prestationen väljer jag att kalla för sportens grundtonsljud (keynote sound, Schafer 1994/[1977]: 272). Exempel på grundtonsljud är det välbekanta ljudet av gnisslande skor mot lackat golv och ljudet av "rasslande" nätmaskor, som är intimt förenade med korgboll: "... det finns ingen ersättning för gnisslet av skor mot lackat golv och ljudet av en korgboll som glider genom nätmaskorna under en korgbollsmatch.". (Novak enligt Bale 1994: 139) Varken Novak eller Bale använder begreppet grundtonsljud, men antyder att ljud är en viktig del av sportupplevelsen. Enligt Schafer är grundtonsljud ständigt närvarande i samhällen, trots att man kanske inte uppfattar dem medvetet, och det är utgående från dessa ljud som alla andra ljud uppfattas (Schafer 1994/[1977]: 272). Truax (1984: 22) nämner att ett grundtonsljud kan vara en del av ambiensen (exempelvis låga elektriska surr) men att det också kan vara en signal som står ut från den bakomliggande ambiensen. Som exempel tar Truax en ambulanssiren i kvarteren kring ett sjukhus. För besökare kan sirenens ljud, enligt Truax, vara en signal, men för den permanenta befolkningen är det ett bakgrundsljud. Ett grundtonsljud för boboll är ljudet som uppstår när klubban träffar bollen. Eftersom det, som ett resultat av bobollens vertikala uppkast till slagmannen, uppstår betydligt flera slag än i baseboll, hör man detta ljud ofta i

6 I Finlands korgbollslandslags hyllningssång Susijengi 2.o hörs både gnisslande skor och ljudet av "strumpan" https:/ / www.youtube.com/watch?v=MtC2ep-d9sc 
boboll. Ljudet av klubban som träffar bollen kan givetvis uppfattas som en signal för att slagmannen har träffat bollen. För en lyssnare som står utanför arenan kan det, likt Truax exempel ovan, signalera att en bobollsmatch pågår, medan det för publiken på arenan är en del av upplevelsen under densamma.

Under min första bobollsmatch förbluffades jag av det smattrande ljud som uppstår då ca 20 spelare värmer upp och fångar hårt kastade bobollar i sina läderhandskar. I takt med att jag blev bekant med bobollens ljudmiljö slutade jag att reagera på ljudet, det reducerades till en del av ambiensen. När någon utespe lare fångar en hårt slagen boll under matchen lyfts dock ljudets betydelse återigen upp. Ljudet av bollen som fångas i handsken en signal för en lyckad lyra: kvalitén på signalen eller sammanhanget i vilken lyran tas, kan väcka reaktioner hos publiken. Ljudet kompenserar också den visuella distansen till händelsen, vilket också gäller när fotbollen eller pucken träffar målstolparna eller ribban. Ljudet blir en signal för hur nära mål det egentligen var och publiken reagerar på ljudet. Utgående från exempelvis enbart det visuella intrycket är det svårt att avgöra styrkan i en tackling mot ishockeysargen.

Enligt bobollsförbundets verksamhetsledare Arto Ojaniemi (Ojaniemi i2012) kan ljudet från en boll som träffar klubban för den insatte lyssnare avslöja hurudant slag det blir. Det är alltså möjligt att utifrån ljudets kvalité höra skruven på bollen och förutse bollbanan. Detta i sin tur väcker förväntningar om vilka vändningar spelsituationen kan ta. Grundtonsljud kan återskapas av i princip vem som helst som utövar sporten. De behöver alltså inte vara bundna till en plats trots att man kan förvänta sig att höra dem i anknytning till en viss spelplats.

Professionell ishockey spelas inomhus i allt bekvämare miljöer som försöker emulera vardagsrummets bekvämligheter. Hallarna konkurrerar med Tv-tittandet med hjälp av bekväma stolar och restauranger samt repriser och statistik som i en TV-sändning skulle skötas av referenten. På väggar och tak finns utrustning för bild- och ljudproduktioner, vilket ger arrangören möjligheter att höja matchupplevelsens underhållningsvärde, men också för marknadsföring av lagets och samarbetspartnernas produkter. Bobolls- och fotbollsarenans regn och rusk står i kontrast till ishockeyns moderna inomhusförhållanden. Enligt Valkonen (1997: 9) spelas ishockey i nordliga och mera traditionella ishockeyländer inomhus av bekvämlighets- och marknadsskäl, men framförallt för att säkerställa de noggranna och regelbundna träningar som toppidrott kräver. 
Boboll lever i symbios med den finska sommaren på ett annat sätt än fotboll för att inte tala om ishockey. För att kunna spela fotboll i Finland tidigt på våren och sent på hösten krävs upplysta planer och uppvärmda gräsmattor, alternativt konstgräs. I dagens läge spelas bobollsfinalmatcherna innan det blir mörkt på hösten och kan på en vardag inledas redan k1. 17.30 i motsats till spelstarten 18.30 för både ishockey och fotboll. Enligt Ojaniemi (i2012) finns det en handfull professionella bobollsspelare i Finland. Man strävar i och för sig efter att göra bobollens förutsättningar bättre i Finland, men att helt professionalisera sporten anser han inte skulle vara ett realistiskt alternativ. Det skulle kräva att matchernas antal måste höjas och säsongen förlängas. Eftersom boboll spelas utomhus från maj till september regleras säsongen i princip helt av den finska sommaren. I Finland är bobollen främst populär ute på landsbygden och en förening som Vimpelin Veto ger sin prägel åt byn, speciellt sommartid. I Vindala sluter samhället upp kring sin förening, barnen leker på spelplanen i halvtid och efter matchen står en stor del av spelarna kvar och pratar med publiken. Vindala har 3204 invånare (Wikipedia) men enligt Superpesis uppgifter (Superpesis 2012) har Vimpelin Veto ett publikmedeltal för år 2012 på hela 2087 personer per match. Familjecentrering, landsbygden och samhällelighet är några ledord som Superpesis lyfter fram i sin matchmanual (Ottelujuontajan kansio 2012: 8). Spelet har under sin snart 100-åriga historia haft mycket stor betydelse för den finländska landsbygden och ett samhälleligt ansvar (se Laitinen 1983).

\section{Från hi-fi till lo-fi}

Att det finns en publik är en grundförutsättning för de flesta professionella evenemang. Publiken vill ta del av sportupplevelsen, vilket, som ovan konstaterades, även innefattar att höra de ljud som, dels utövarna men, också publiken producerar. Erkki Tuovinen (2007: 30), som har forskat i fotbollsångers identitetsskapande roll, anser att publiken är medveten om sin roll i helheten och att det är en oskriven lag, eller kanske mera ett behov, för åskådaren att bidra med ljud. Sociologen Les Back (2003) lyfter fram att även om det heter att "se på en match" är fotboll mer än bara det visuella, om det vittnar blinda fans som besö- 
ker fotbollsmatcher för atmosfärens skull. Han konstaterar att sportupplevelsen handlade lika mycket om ljuden som om det visuella uttrycket (Back 2003: 311). John Bale (1994: 140), som har forskat i sport och upplevelse av plats, anser att ljud och musik är en central del av sportupplevelsen.

Att höra är, enligt Truax (1984), att ta emot akustisk energi i form av ljudvågor och vibrationer medan att lyssna är kärnan av en kommunikativ modell där man processar information som är användbar och meningsfull för hjärnan. Som ovan konstaterades är exempelvis de ljud som utövarna producerar användbara och meningsfulla. Truax kommunikativa modell kan appliceras på många olika kontexter och han konstaterar att när systemet är välbalanserat (hi-fi) utbyts mycket information mellan elementen ljud, lyssnare och miljö. I en lo-fi miljö går det däremot mycket information till spillo. (Truax 1984: 9-10.) Truax modell utgår från inte bara överföring av energi utan också överföring av information. Schafer har konstaterat att den elektroniska revolutionen medförde att man kunde paketera och förvara ljud men även att man kunde separera ljud från dess ursprungliga kontext, något som ledde till att världen började övergå till lo-fi ljudmiljöer (Schafer 1994/[1977]: 88-89, 272).

Veikkausliigas vD Timo Marjamaa konstaterar att den finska publiken är rätt behärskad (Marjamaa i2012) och Jaros publik är enligt mig inget undantag. Att publiken är mera behärskad, i förhållande till andra europeiska fotbollsländer, får Marjamaa att lite tillspetsat dra slutsatsen att man i Finland är mera av "idrottsgranskare" (urheiluntarkkailija) än supporter (urheilunkannattaja) men han tror att den finska publikens beteende sakta kommer att förändras med åren. När nya generationer tar till sig influenser från den internationella nivån och lär dem vidare till sina egna barn kommer hela kulturen, inte bara under sportevenemang utan även andra tillställningar, att förändras. Evenemangets framgång beror inte bara på de som uppträder eller vad man ser på. Med sin egen insats kan man göra händelsen mycket mera framgångsrik, gladare och levande. (Marjamaa i2012) Eftersom man inom den finska fotbollen inte når upp till likadan stämning som på de europeiska arenorna blir man ibland pinsamt medveten om hur hi-fi fotbollsmiljön kan vara. Den kommunikation som spelarna för på planen når ibland även publiken, vilket den inte skulle göra om en hejarklack skulle föra liv. Avsaknad av publikljud ger rum även för individuella rop att höras, även från publikplats. 
Publika tillställningar inför en stor åskådarmassa är per definition inte negativa lo-fi miljöer. Som ovan har konstaterats anser jag att publikens ljud är en naturlig del av att uppleva sport, det är inget oljud utan synnerligen meningsskapande, ja en av orsakerna till varför man vill uppleva sport. Schafer använder lo-fi som ett begrepp för miljöer där ljud täcker varandra, det vill säga mängden akustisk information gör att ljuden inte kan urskiljas klart. Dock är det främst möjligheten att reproducera ljud samt modern teknik som bidrar till Schafers klassificering. Bland annat Andra McCartney (2010) har lyft fram problematiken med romantiseringen kring hi-fi begreppet och konstaterat att det även finns ljudliga platser i naturen med överlappande ljud samt lo-fi platser i den urbana staden som människor aktivt uppsöker. McCartney lyfter också fram hur ljud tack vare modern teknik har blivit elektroniska signaler och frågar sig om en "clear signal articulation" också kan reflektera ett ohälsosamt system.

Kampen om vem som kan höras skapar en form av auditiv Darwinism, alltså den starkaste, mest outtröttliga överlever i lo-fi miljöer. Här förs en ojämn strid mellan natur och teknik. Schafers inställning till teknik har till och med ansetts vara teknofobisk. Hejarklackar tävlar i ishockeymiljö inte bara med det andra lagets eventuella supportrar om herraväldet i luften, det finns främst under spelavbrotten också en konkurrens med andra elektroakustiskt förstärka ljudhändelser, exempelvis musik. Det är dock all anledning att komma i håg att även bortalagets supportrar kan göra sig hörda med en liten ettrig hejarklack i sådana spelsituationer där hemmapubliken är tyst, vilket till exempel kan ske då bortalaget gjort mål (Ahlsved 2012f). Back (2003: 320) anser att även om hejarklackarnas sånger alltid är riktade till en publik handlar det inte om kommunikation utan om att vara affektiva, alltså höja hemmalaget spel eller att kväva (stifle) motståndarna. Enligt Jaros vd Niklas Storbacka är Jaros supportrar, de gånger man har haft en större grupp, kända för att vara "positiva" fans som trots dystra resultat orkat heja på de egna utan att börja hacka ner på motståndarna (Storbacka \& Wargh i2012). Man kan givetvis försöka kväva motståndarna genom själva budskapet men också genom ljudmassan man producerar. Den turkiska supportergrupp som Meri Kytö har studerat (2011) är känd för att vara exceptionellt högljudd. I bästa fall kan alltså en högljudd publik inte bara kväva, alltså dölja, ljuden från motståndarnas hejarklack utan också dölja sportens grundtonsljud. Detta ska inte tolkas som något negativt trots att ljudmiljön per definition blir mera lo-fi. 
Snarare är det oftast en kvalitativ bedömning på publikens ansträngningar och resultatet en bättre stämning.

Man kan däremot hävda att relationen mellan lyssnaren och miljön förändras när arrangören tillför mekanisk musik till ljudlandskapet, oberoende av vad arrangörerna ursprungligen avsett med musiken. Eftersom jag studerar sporter där mekanisk musik inte är en förutsättning för utövande av sporten är resultatet av den musik och de ljud som arrangören spelar en mera lo-fi miljö. I synnerhet möjligheten att reproducera och elektroniskt förstärka ljud har lett till konkurrens om utrymmet man får i ljudmiljön. Detta gäller inte bara i förhållandet mellan eventuella supportergrupper utan också i förhållande till musik och reklamer.

I ishockey har det blivit något av en norm att spela musik under de korta spelavbrott som ofta uppstår i matchen. Överlag konstaterar HC TPs dj, som går under dj-namnet mylbeee, att publiken på HC TPs hemmamatcher reagerar väldigt lite på musiken i jämförelse med hans erfarenheter från exempelvis landslagsmatcher, där publiken till och med kan försöka haka på musik som inte direkt lämpar sig att klappa i händerna eller dansa till (mylbeee i2012). Under mina fältarbeten har jag observerat samma sak. Det kan till exempel hända att publiken börjar klappa i ett gemensamt kollektivt accelerando på ett sätt som inte verkar interagera med den musik dj:n spelar:

"Pucken flyger ur rinken i Ilves zon och det blir spelavbrott. Iku Viitanen, som sköter de inofficiella utannonseringarna, förkunnar att "Mikkoooooo Koivuuuu" var den som gjorde både 2-4 och 3-4 målen. Publiken jublar och spelarens fadderföretag presenteras. Efteråt följer reklam. TPS-ropen tar fart igen under en ljudmatta av reklam: ett crescendo och accelerando av "Tee-Pee-Äss". När reklamen tar slut hörs ropen tydligt. Det blir plötsligt lite tid över för musik då TPS överraskande nog byter målvakt. Matchens officiella speaker utannonserar bytet och efter det lägger dj:n igång Bullets And Octane's låt Pirates. Låten är åt punk/ rock-hållet. Reaktionerna från publiken är obefintliga [...]. Precis som under de senaste spelavbrotten börjar publiken, ledda av hejarklacken, sakta men säkert att applådera taktfast i ett gemensamt accelerando under musiken. När pucken släpps ner på isen och musiken tystnar har man nått full fart, inte tack vare musiken utan trots musiken. (Ahlsved 2012f.) 
Detta är ett exempel på en lo-fi ljudmiljö där ljuden överlappar varandra och den potentiella kommunikationen störs, framför allt av möjligheten av att reproducera ljud. Publiken måste, både fysiskt och psykiskt, ta sig igenom den musik eller reklam som spelas för att överhuvudtaget göra sig hörd. Detta är inte något som är specifikt för HC тPs. Tanken om den naturliga balans som finns i orörda ljudlandskap kan på en abstrakt nivå även appliceras till sportens ljudlandskap. Detta trots att det är lika svårt att hitta orörda ljudlandskap i naturen som det är att hitta publiksporter där man inte använder sig av elektroakustisk reproducerade ljud.

En tidig dokumentation av organiserat "hejande" är enligt Oriard (1981: 39) när Princetons spelare år 1869 tränade några av sina klasskamrater att heja på dem inför en returmatch mot Rutgers. I det första mötet hade Princetonspelarna själv försökt störa motståndarna genom att ropa, men det resulterade bara $\mathrm{i}$ att spelarna tröttnade snabbare. Oriard konstaterar att det här fanns en direkt koppling mellan spelare och publik, en koppling som idag inte är möjlig i amerikansk fotboll eftersom mängden information i spelavbrotten leder till en "sensorisk överbelastning" som passiverar publiken och fjärmar den från upplevelsen. Skillnaden mellan fotboll och amerikansk fotboll är att det i amerikansk fotboll är spelavbrotten som skapar det välorkestrerade dramat, menar Oriard. Men eftersom man är rädd för spelavbrottens tystnad, där fansen borde kunna planera och diskutera lagets följande drag, har man med bland annat distraherande cheerleaders förvandlat sporten till enbart action där fansen endast är aktiva när spelet väl är igång. (Oriard 1981: 38-40.)

Schafer (1994/[1977]: 237) har konstaterat att "när ett samhälle fumlar med ljud, när man inte förstår grunderna med anständighet och balans i ljudskapande, när man inte förstår att det finns en tid att producera och en tid att vara tyst, då övergår ljudlandskapet från hi-fi till lo-fi och konsumeras i kakofoni." Kakofonin av ljud är det som Schafer kallar för schizofonia (Schafer 1994/[1977]: 273). Med det syftar han på möjligheten att reproducera ljud från en annan tid och plats. Truax (1984: 120) använder också begreppet som en splittring mellan ett originalljud samt en elektroakustisk reproduktion och menar att utmaningen med den schizofona situationen är att lyssnaren själv måste skapa sammanhanget. Vi har vant oss vid schizofonin, det vill säga möjligheten att separera ljud från dess ursprungliga källa, och accepterar att det strömmar "musik ur väggar och 
tak" (Truax 1984: 120). Schizofonibegreppet har en negativ underton men trots trägna debatter har man, enligt Heikki Uimonen (2005: 61), inte lyckats lansera en vedertagen neutralare term. I Finland har ljudlandskapsforskare, bl.a. Uimonen (2005), lyft fram termen "transfonia" som på ett mera neutralt sätt syftar på möjlighet att förflytta ett ljud från sin ursprungliga kontext.

På ett professionellt evenemang är det inte bara musik som strömmar ur väggar och tak. Ur framförallt ishockeyhallarnas jumbotroner bombarderas publiken med videoreklam, men också med statistik, repriser och intervjuer. Den stora mängden visuell och auditiv information är resultatet av transfonin, dvs. möjligheten att flytta ljud men samtidigt också information från ett ställe till ett annat. Detta kan bidra till en krävande ljudmiljö där lyssnaren själv måste kontextualisera ljuden och den information som ljuden bär med sig.

Detlev Ipsen (2002), som har kritiserat Schafers begrepp schizofonia, konstaterar att det inte är skillnaden mellan rurala och urbana miljöer som producerar hi- eller lo-fi, utan den mängd akustisk komplexitet som tas i beaktande när man utvärderar miljöer. Ipsen anser att miljöer med hög komplexitet kan väcka vår uppmärksamhet. Ifall en situation är överfull med information försöker man fly den, men ju mera bekant en person är med en viss miljö desto mindre komplex blir informationen för personen. Komplexiteten är resultatet av ett dynamiskt förhållande mellan en persons förmåga att anpassa sig och informationens egenskaper. Enligt Ipsen varierar denna relation mellan olika individer och kulturella grupper. (Ipsen 2002: 189-191) Istället för begreppet schizofonia föreslår Ipsen (2002: 194-196) olika mönster för ljudlandskap. Ett syntetiskt ljudlandskap är, enligt Ipsen (2002: 195) "en kombination av bilder och ljud som normalt inte passar ihop". Den tekniska utrustning som möjliggör transfonin gör det också möjligt att använda sig av en speaker som i stil med en tv-referent förklarar vad som sker i den väldigt taktiska bobollen. Att en persons röst överförs från ett rum högt uppe under Saarikenttäs tak och hörs över hela stadion är idag inte särskilt anmärkningsvärt men när informationsflödet kan innefatta förinspelade videoproduktioner, intervjuer från sargkanten, musik, reklamer och statistik, skapas ett nytt mera syntetiskt ljudlandskap i högre grad än tidigare. Detta ställer högre krav på publikens förmåga att anpassa sig och att själv skapa mening av informationen. Det kan också betyda att man måste kunna sålla bort den information man anser var överflödig eller meningslös för situationen. 
Den publik som är van vid ishockeymiljön, eller som sällan upplever sport annat än på tv kan reflexmässigt söka efter en repris även i sammanhang där repriser inte existerar. Slow-motionsekvenserna och bilder med information om spelarna, med eller utan musik, ger evenemanget en extra krydda, samtidigt som de fyller ut spelavbrott med för publiken väsentlig information. Mängden information som en individ kan hantera menar Ipsen (2002: 191) varierar på personnivå. För att ett evenemang ska vara framgångsrikt ligger det $i$ arrangörens intresse att skapa en helhetsmiljö där publik, spelare och annonsörers behov möts. Därför borde man sträva efter att skapa så positiva miljöer som möjligt för att undvika situationer där publiken inte kan skapa mening av alla ljud. I lo-fi miljöer går mycket energi till spillo och Bale (1994) och Oriard (1981) varnar för att för mycket underhållning i bland annat spelavbrotten kommer att förändra sportens ljudlandskap slutgiltigt genom att publiken passiveras. Ljudlandskap inom modern professionell sport håller på att blir mer och mer syntetiska, alltså mera lo-fi enligt Schafers definition.

\section{Ljudlandskapskompetens i sportsammanhang}

För att kunna verka i schizofona eller syntetiska miljöer behöver man ljudlandskapskompetens (soundscape competence). Enligt Heikki Uimonen (2011: 47) är ljudlandskapskompetens en individs unika, men också kulturbundna förmåga att förstå ljud som meningsfulla och kunna agera utgående från denna förståelse. Kombinationen av publikens ljud och visuell information, såsom reklamer på bildskärmar, cheerleaders och annonser i ljudform, gör att det i speciellt en ishockeykontext finns mycket musik och ljud som försöker dra publikens uppmärksamhet till sig. Kännedom om grundläggande strukturer ger lyssnaren en förståelse för kontexten och samtidigt en bättre möjlighet att skapa mening av informationen. Truax (1984: 50) konstaterar att man behöver ljudlandskapskompetens för att kunna vistas i olika miljöer och det ger oss möjlighet att förstå ljud som meningsfulla. Det handlar alltså om att förstå hur ljud skapar mening i en viss kontext. Uimonen påpekar (2005: 134) att personer som kommer utifrån kan uppfatta vardagliga ljud som intressanta (som jag gjorde under min första bobollsmatch) medan personer som vistas i en miljö dagligen kan ha lättare att uppfatta även 
små, subtila förändringar i ljudlandskapet. Även för lyssnare med inifrånperspektiv kan det bli krävande att koncentrera sig på det som är meningsfullt om mängden information blir för stor. Oriard (1981: 38-39) anser att mängden oväsentlig information är så stor i amerikansk fotboll att publiken inte kan koncentrera sig på de taktiska strategierna som görs upp främst i spelavbrotten. Det handlar alltså inte bara om informationens karaktär utan också om mängden information.

Truax (1984: 20) poängterar att hi-fi ljudlandskap förstärker en positiv relation mellan individen och miljön medan man i lo-fi miljöer kan ha känsla av att behöva bryta sig igenom den för att interagera med andra. Detta kan enligt Truax resultera i att man isoleras, även om lo-fi miljöer inte alltid annars skulle vara negativa och passiverande. Detta exempel ur en ishockeymiljö illustrerar hur musik också kan vara aktiverade:

\footnotetext{
"En TPS-spelare dras ner och publiken reagerar kraftigt på tacklingen. Ilves får, till hemmapublikens stora förtjusning, en utvisning. Utvisningsmusiken Hit The Road Jack drar igång genast. Publiken, inklusive hejarklacken, hakar på musiken och "pekar" mot spelaren och utvisningsbåset." (Ahlsved 2012f.)
}

Hit The Road Jack är en få låtar i en TPs-kontext som får igång publiken, men sammanhanget spelar en stor roll för publikens vilja att interagera. När laget kanske inte spelar så bra eller är ordentligt på förlust verkar samma musik inte lika engagerande. Mållåtar, det vill säga musik som publiken får klappa och sjunga med efter att det egna laget har gjort mål, används av både TPS och Jaro. Möjligheten att delta i musiken förstärker likt exemplet ovan den gemensamma identiteten. Mållåtarnas kvalitet och lämplighet för laget är oftast föremål för diskussion och överskuggar helt diskussioner om varför musik överhuvudtaget behövs i den euforiska stunden. Lo-fi, schizofona miljöer är således inte nödvändigtvis förknippade med enbart något negativ så länge individen kan interagera. Långvarige speakern och tidigare TPS-dj:n Iku Viitanen (i20o8) har poängterat att det under exempelvis slutspel eller finaler, eller i stunder då matchen är verkligt intensiv, kan vara lika viktigt för publiken som för spelarna att hämta andan under spelavbrotten. Musiken håller intensiteten uppe medan publiken hämtar andan en stund. Man bör dock notera att detta är sällan återkommande situationer. 
Åskådarens motiv för att besöka matchen påverkar också hur han eller hon interagerar under evenemanget. En lojal åskådare beter sig inte på samma sätt som den sporadiske besökaren som kanske besöker matchen endast för stämningens skull. Den sporadiske besökaren saknar kanske personlig koppling till laget och kännedom om miljön och slänger sig stereotypiskt med i matchupplevelsen. (Anttila 2001: 68-71) Åskådarnas beteende formas av återkommande rytmer i ljudlandskapet. Kännedom om rytmerna är en del av ljudlandskapskompetensen trots att man inte alltid aktivt noterar dem.

\section{Rytmer och traditioner}

Sport är underhållande drama som kan förliknas med andra dramatiska föreställningar som sker i slutna lokaliteter. Matchen och hela evenemanget runt omkring den är ett drama i sig där "skådespelarna", alltså spelarna, liksom publiken vet sina roller. Den största väsentliga skillnaden mellan sportdramat och teaterdramat är att utgången i en match inte är överenskommen i ett manuskript på förhand. Enligt Jukka Ammondt kan sport förliknas vid ett drama där publiken känner till reglerna på förhand och där den eventuella segern eller förlusten klarnar entydigt i slutet av matchen, till skillnad från ett teaterdrama där slutet kan lämnas öppet för tolkning (cit. i Asposalo et al. 2001: 85). Sportdramat är också oregelbundet i den mån att man inte kan förutse själva matchförloppet, förutom att helheten spjälks upp i delar, såsom perioder. Denna periodisering ger matchen också en rytm. Enligt Schafer (1994/[1977]: 226) försöker människan alltid skapa en form av det slumpmässiga samt uppfatta mönster. Han konstaterar att rytm delar upp en helhet i olika delar och för att förstå hur ett ljudlandskap sitter ihop behöver man förstå dess rytm. (Schafer 1994/[1977]: 226) Vi bär med oss många rytmer, till exempel hjärtats rytm, men vi skapar också rytmer i vår omgivning genom de steg vi tar. Redan tidigare konstaterades att årstidsrytmen är viktigt för bobollen medan det finska klimatet ger fotbollen utmaningar på våren och hösten. Ishockeyn däremot har med sina ishallar gjort sig oberoende av årstidsrytmen.

Musiken kan fungera som en gräns för vad som hör till ljudlandskapet. Hela evenemanget ramas in med musik, med början i den bakgrundsmusik som spe- 
las då publiken håller på att samlas. Ett organiserat ljudlandskap med mänskliga ljud förkunnar att det finns människor på plats, du är inte ensam. Enligt Ola Stockfelt är den musik som spelas som bakgrundsmusik i olika sammanhang inte där för att man ska lyssna lika aktivt på den som musiken på en konsert. Musik finns där för att dölja oönskade ljud och samtidigt göra den urbana konstruktionen mera mänsklig (Stockfelt 1988: 155). Musiken kan givetvis också fungera som en "bakre gräns", det vill säga som ett tecken på att matchen är slut. På Vimpelin Vetos matcher har man tidigare haft en tradition att spela Bron över floden Kwai efter matchen (Kujala i2012) medan mylbeee säsongen 2012-2013 har kompletterat HC тPs traditionella "segermusik", Kai Hyttinens låt Dirlandaa, med en "förlustlåt", nämligen reggaegruppen Kuningasideas Enemmän duoo ku soloo. Eftersom mylbeee publicerar sin spellista som live-tweets från hemmamatcherna kan mangenom att läsa hans tweets inte bara registrera när evenemanget har börjat och slutat men också utläsa om TPs har vunnit eller förlorat matchen.

Den rytm som i det här sammanhanget är speciellt viktigt att lyfta fram är den som de olika sporterna har när matchen väl är igång eftersom den påverkar. publikens deltagande men ännu mera arrangörens möjlighet att spela musik. Ljudlandskapet får en viss rytm av återkommande spelavbrott och pauser. Även om vissa pauser går att förutse är största delen av spelavbrotten oregelbundna både gällande längd och antal.

De sporter jag har studerat har alla olika sätta att dela in sina matcher i olika "avsnitt". Längden på en fotbollsmatch är 90 minuter medan en ishockeymatch spelas i 6o minuter. Fotbollsmatchen är uppdelad på två halvlekar á 45 minuter var med en paus på max 15 minuter. Boboll har inte tidtagning överhuvudtaget och därför är det inte ovanligt att en bobollsmatch ibland kan ta upp emot tre timmar. Bobollsmatchen är indelad i två perioder och det lag som spelar inne har slagtur. Lagen ska spela inne respektive ute fyra gånger per period. Ishockeymatchen har tre 20 minuters perioder och två pauser á 18 minuter. Periodpauserna i alla tre sporter är förväntade pauser som arrangören fyller med reklam eller underhållning. Den tid som blir över fylls med musik men det är inte ovanligt att man ibland knappt hinner spela någon musik alls i periodpauserna. Detta gäller för alla tre sporter.

Om fotbollen hamnar ur spel och domaren blåser av spelet för exempelvis frispark signalerar han igen med sin visselpipa när frisparken får slås. Den tid 
som matchen har varit avblåst kompenserar domaren i slutet av varje halvlek med extra tid. Matchklockan stoppas alltså inte. Det betyder att den aktiva speltiden alltid blir 9o plus eventuell övertid. Med pausen inräknat tar en fotbollsmatch normalt under två timmar. Publiken har rätt att när som helst bidra med sina ljud till ljudlandskapet, kanske t.o.m. långt innan matchstart (se Kytö 2011), men det är inte tillåtet att spela musik så länge bollen är i spel. Detta står dock inte utskrivet någonstans i regelverket (Lundström i2012). Inga sporter har någon regel som förbjuder musikanvändning under matchen, det antas vara självklart. Vid till exempel frisparkar och hörnor är det alltså tillåtet att spela musik trots att väldigt få arrangörer väljer att göra det. Hörn-, inkast-, och frisparkssituationer är en del av den oregelbundna rytm som formar fotbollsljudlandskapet. För publiken är det egentligen fritt fram att heja och sjunga när som helst, men publiken tenderar att aktivera sig vid fasta, återkommande situationer.

Veikkausliigas vD Timo Marjamaa (i2012) konstaterar att det är önskvärt att det inte förekommer störande ljud när spelet är igång. När spelet är igång ska det vara fritt fram för de [i publiken] som vill föra ljud. Men det finns enligt Marjamaa inget som förbjuder arrangören att försöka tända hemmapubliken med musik vid till exempel hörnsituationer: "Dylika småskaliga sätt att utveckla stämningen fördöms inte. Om det helt klart fungerar och inte stör publiken utan publiken gillar det, deltar entusiastiskt och det bidrar med matchstämning så givetvis [ska man tillåta det]. Det vore orimligt att förbjuda något sådant" (Marjamaa i2012). Den manual med regler som Veikkausliiga årligen ger ut är ett verktyg som skall trygga att föreningarnas arrangemang håller en viss kvalitet, men det är upp till föreningarna att tolka manualen på lokalnivå. Enstaka föreningar har under säsongen 2012 spelat rikligt med musik och reklamer i hörn- och frisparkssituationer, vilket också har noterats i Jaro-ledningen. Jaros marknadsföringschef Jimmy Wargh, som ansvarar för försäljningen av Jaros ljudreklamer, skulle gärna använda återkommande situationer för reklamer. Det är mycket lättare att sälja reklamer när man kan garantera att man har en "sittande publik" (Storbacka \& Wargh i2012). vD Storbacka skulle hellre bygga upp stämningen med musik. Det skulle kanske ge klirr i kassan på längre sikt men Storbacka är tveksam om man ens får använda musik. Lundström (i2012), som själv lite skämtsamt kallar sig personligen för en "puritan", eftersom han inte vill ha mu- 
sik i spelavbrotten, anser att man på bollförbundet inte kan börja göra listor med vad som är förbjudet. Ifall musiken ger hemma- och bortalaget olika sportsliga förutsättningar att verka har dock förbundet möjligheter att ingripa, även under matchens gång (Lundström i2012).

Traditioner inom supporterkulturen är den del av sportens ljudlandskap som vid sidan av sociologiska frågeställningar har fått mest vetenskaplig uppmärksamhet. Tuovinen (2007) och Kytö (2011) har med sin forskning visat hur organiserade supportergrupperna kan vara. En fotbollspublik brukar, enligt Tuovinen (2007: 10) under en match grovt indelas i två olika delar: hemmalagets och bortalagets supportrar. Största delen av publiken hör inte till någon supportergrupp, deras inställning är mera neutral trots att de hejar på någotdera av lagen (Tuovinen 2007: 10). Inom finsk fotboll finns det ofta inte mycket mer än en handfull bortasupportrar på matcherna. Uppdelningen blir med andra ord inte lika tydlig som på internationella arenor, där supportergrupperna ofta anvisas till separata delar av arenan, delvis för att undvika gruff med motståndarnas supportrar men också för att det i fotboll är kutym att man sjunger bakom målen. HC TPs har vigt en egen läktarsektion åt sin hejarklack från vilken de sjunger under ledning av en försångare med megafon.

Enligt Tuovinen (2007: 15) är sångerna som sjungs på fotbollsarenor funktionsmusik med syftet att få en yttre händelse till stånd. Med sångerna organiserar och aktiverar man hejarklacken och skapar en gemensam identitet. Genom att både synas och höras så enhetligt som möjligt ger man bilden av en kompakt mur, som är ogenomträngbar för motståndarlaget (Tuovinen 2007: 15). Som redan tidigare konstaterats anser Back (2003: 320) att hejarklackarna strävar efter att höja hemmalagets spel samtidigt som man försöker kväva motståndarna. HC TPS marknadsföringskoordinator konstaterar (i2013) att HC TPS hejarklack försöker anamma en mera europeisk, fotbollsinspirerad hejarklackskultur och hejarklacken är mån om sin egen självständighet vilket också noteras i förhållande till musiken dj:n spelar. Mylbeee (i2013) har noterat att det är bara när han spelar klassikern Tepsi tekee kohta maalin som även hejarklacken hakar på musiken. Sången, inspelad av Seitsemän Seinähullua Veljestä7 (1976) på melodin till The

\footnotetext{
7 Tepsi Tekee Kohta Maali, som egentligen heter Nyt Teps!!, fungerar som hymn för hela TPs organisation, i vilken det även ingår andra sporter som fotboll, innebandy och bowling. http:/ /www. youtube.com/watch?v=D-iRmiZxrjk
} 
Battle Hymn of the Republic ("Glory, Glory, Hallelujah"), är den som också oftast tänder en större del av publiken. Den används oftast när TPs har tryck på motståndarna t.ex. vid power play:

Spelavbrott och tekning i Ilves zon. Först kommer en reklam, sedan spelas Tepsi

Tepsi Tekee Kohta Maalin. Taket i hallen håller på att lyfta när publiken sjunger med. DJ:n bryter musiken så att publiken ensamt får sjunga sista raden i sången "eikä Ilves sille mitään voi!". Publiken skarvar själv till med ett extra "ei voi". (Ahlsved 2012f.)

Den smått retsamma sången har blivit en evergreen inom finländsk läktarkultur och har spridits långt utanför sportens gränser. Men hejarklackens "ovilja" att delta i den övriga musiken gör att de drunknar i spelavbrottens musik. Deras och dj:ns musik "kolliderar" och ger hejarklacken en ofördelaktig lo-fi-situation där de måste bryta sig igenom den spelade musiken. Krocken mellan en europeisk och nordamerikansk läktarkultur kan skildras så här:

Cirka 11 minuter in i period två noterade jag att hejarklacken tog i extra mycket efter ligans standardiserade reklampaus ("s M-liigatauko"). Det blev av någon orsak en lucka i ljudlandskapet som hejarklacken genast förvaltade och man fortsatte att sjunga när spelet kom igång igen. Sången avtog så småningom och hejarklacken påbörjade en ny sång. I följande spelavbrott spelades Joe Satrianis Crowd Chant i princip över klackens sång. Någon noterbar interaktion eller respons på den mekaniska musiken fanns överhuvudtaget inte. Klacken fortsatte att sjunga sitt under Satriani-låten men gav upp efter en stund. När spelet blåstes igång igen började man sjunga på ännu en ny sång. (Ahlsved 2012f.)

Då Lauri "Tahko" Pihkala utvecklade bobollen kring år 1920 ville han genom det vertikala sätt som klockaren kastar upp bollen till slagmannen öka antalet slag i jämförelse med baseball. Samtidigt kan slagmannen också kontrollera bollbanan bättre och spelet blir mera taktiskt. Varje slagman har tre försök på sig att slå iväg bollen så att han och medspelarna kan ta sig till följande bo. Klockarens och utespelarnas taktiska "lekar" där man kastar bollen sinsemellan för att få rörelse bland spelarna ute i bona och för att rubba slagmannens koncentration är en del 
av lagens taktiska kamp. Ända tills bollen har lämnat klockarens hand vertikalt är det tillåtet att spela musik. Detta trots att den psykologiska kampen och medspelarnas taktiska rop och bluffrop i samband med slagen är en viktig del av bobollen. Det föreligger en viss risk i att spelarnas ljud dränks av den eventuella musik som spelas. De lag som väljer att spela musik i detta sammanhang har, enligt mina observationer, svårt att få den synkroniserad med situationens oförutsägbarhet.

På Vimpelin Vetos hemmamatcher deltar publiken väldigt aktivt i matchhändelserna trots att det inom bobollen, enligt Ojaniemi (i2012), är ovanligt med hejarklackar. Vimpelin Vetos väldigt kunniga bobollspublik (Ojaniemi 2012) deltar ofta med accelererande rytmiska applåder när en hemmaspelare har slagtur. Detta, i kombination spelarnas "väärä"-rop (som innespelarna ropar genast när motståndarens klockare, avsiktligt eller av misstag, kastar en felaktig, regelvidrig boll åt slagmannen), är en mycket väsentlig del av att uppleva boboll. När hemmalaget spelar inne "vet" hemmapubliken att man i dylika återkommande spelsituationer ska bidra med motiverande ljud precis som förväntningen är vid till exempel hörn- eller frisparkar i fotboll. Trots att det inom boboll är tillåtet att spela musik fram till dess att bollen har lämnat klockarens hand (Ojaniemi i2012) har Vimpelin Veto valt att inte spela musik varken då hemma- eller bortalaget har slagtur. Kampen om herraväldet i ljudlandskapet blir således jämställt att hemmalaget oftast har en numerär fördel på grund av hemmaplan. Att inte spela musik är ett medvetet val (Kujala i2012, Ojaniemi i2012), och med detta förfarande ger man publiken utrymme och möjlighet att var delaktig på sportens egna villkor.

I boboll förekommer det att publiken försöker förhindra bortalagets kommunikation genom att ropa högljutt när bortalaget har slagtur. Detta är speciellt påtagligt vid Vimpelin Vetos hemmamatcher. I Sotkamo skrek publiken speciellt under 1990-talet "kuolee" för att genom en samlad aktion förhindra bortalagets kommunikation (Kujala i2012). Det osportsliga i Sotkamo-publikens förfarande har också ifrågasatts på olika forum på nätet (Suomi24 2008), men trots att Kujala (i2012) inte vet hur organiserad aktionen var, tycker han i alla fall inte att det är osportsligt beteende av publiken. Det krävs en stor publikmassa för något sådant och om publiken får en sådan ljudmassa till stånd som gör att spelarnas "väärä-rop" inte hörs är det helt enkelt hemmaplansfavör, 
menar Kujala. Enligt honom finns en sådan publik i Vindala trots att man inte har någon specifik hejarklack. Det är alltså accepterat, till och med uppskattat, att publiken som inte begränsas av de tidsmässiga reglerna bidrar till att ljudmiljön, för spelarnas del, blir mera lo-fi. Genom att överrösta "väärä"-ropen kan man eventuellt också påverka spelets gång. Men om det görs med mekanisk musik uppskattas det inte. Kujala anser att om man spelar musik då motståndarna har slagtur kan detta tolkas som "störande musik". "Vi har inte heller sysslat med sådant. Det är jämlikt för båda och publiken ropar vad de nu sen ropar" konstaterar Kujala (i2012). De som enligt Kujala besöker Saarikenttä för första gången kan förvånas över att det under matchens gång är publiken som väsnas och inte ljudanläggningen eller högtalare. Även jag förvånades, trots att det inte var min första match:

\footnotetext{
"Publiken deltar mycket aktivt i spelet. Vilket otroligt skrikande i första vuoro ('omgången') då Joensuu börjar inne, dvs. Då Joensuus spelare är närmast publiken! Publiken försöker aktiv störa slagmannens koncentration, inte direkt genom att skrika osakligheter utan med ljud." (Ahlsved 2012b.)
}

Ovannämnda match gick ända till så kallad "supervuoro" (superomgång), dvs. till en förlängning av matchen där vartdera laget spelar ute respektive inne en sista gång och den som får mest poäng vinner matchen. När Joensuu hade avgörandet i sin hand var ljudet närmast öronbedövande ${ }^{8}$. Varenda gång Joensuus klockare stod i beråd att kasta bollen uppåt, åt slagmannen, förde hemmapubliken ett förfärligt ljud. Ifall klockaren beslöt att kasta bollen inåt i spelplan till en medspelare avtog ljudet för stunden. Varje gång klockaren åtminstone till synes gjorde sig beredd att kasta bollen uppåt var publiken igen aktiv med sina störande ljud. (Ahlsved 2012b) Med sin insats försöker publiken alltså genom att göra ljudmiljön mera lo-fi påverka slagmannen och bortalagets strategi. För att ljudlöst kunna kommunicera med spelarna ute i boen har i lagen utvecklat olika visuella sätt att kommunicera.

8 För ett exempel på detta ropande från en annan av Vimpelin Vetos hemmamatcher, dock inte riktigt lika öronbedövande, se t.ex. 4'33-6'03 i filmklippet https://www.youtube.com/ watch?v=EOYTDKZzTvg 
Jaro och Vimpelin Veto förlitar sig på att det är publiken som ska skapa stämningen på matchen, publikens ljud uppskattas mera än eventuell musik från arrangörshåll. Ishockeyarenan har som tidigare konstaterats inte bara bättre verksamhetsförutsättningar för att skapa en mera komplex ljudmiljö. Skillnaden i sättet att mäta speltiden bidrar också eftersom man vid varje spelavbrott $i$ ishockey stoppar tiden och det uppstår ca 25 sekunder långa spelavbrott. Dessa återkommande oregelbundna avbrott var enligt Valkonen (1997: 85) en av orsakerna till att ishockey blev en kabelteveprodukt i Nordamerika på 1970-talet. Avbrotten mitt i matcherna var inte lämpliga för reklampauser. FM-ligan har dock rått bot på detta och infört två officiella reklampauser i varje period. I pauserna kan TVbolagen visa reklamer medan ligans samarbetspartners reklamer visas i hallarna under den tid som isen förbättras av sponsorerade "Ice Girls". Utmaningen med sportens oförutsägbarhet är att matchen kan innehålla få spelavbrott, vilket ger mindre rum för reklam och musik.

Den kanske största skillnaden mellan de olika kulturerna blir speciellt tydlig i de sista spelavbrotten av en förlustmatch i ishockey. Även om matchen ur hemmalagets synvinkel är förlorad och en del av publiken kanske redan har gått hem, spelarna har gett upp och inte ens hejarklacken orkar sjunga, förkunnar spelavbrottens musik att "the show must go on". I en motsvarande fotbollssituation skulle publiken antagligen också avlägsna sig alternativt lida genom de sista minuterna under en tyst tryckt stämning. Det är i brytningspunkterna mellan dessa uttryck på hi-fi och lo-fi som man kan bli medveten om den stora mängd information som finns alldeles specifikt $\mathrm{i}$ ishockey. Även om hemmalaget får stryk redan i första perioden är det bara att fortsätta som vanligt trots att musiken, liksom matchen är förlorad (mylbeee i2013). Med förlorad syftar mylbeee på att musik plikttroget spelas ända till slut trots att publiken kanske har tappat intresse för både matchen och musiken. Det finns en förväntning på användningen av musik och denna förväntning förpliktigar också. Musiken är numera en självklar del av professionella evenemang och få ifrågasätter musikens existens. Webbforum fokuserar snarare på att diskutera lämpliga musikstycken för evenemangen. Att musiken är ständigt närvarande gör dj:ns roll ännu viktigare. Det är trots allt han som ska avgöra vilken musik som är meningsfull att spela och det står alltid i relation till sammanhanget. 


\section{Strategier}

Flera lag har också utvecklat olika sätt att förändra balansen i ljudlandskapet och därmed också stämningen på sina matcher. Schafer syftade med sin forskning inte bara på att studera ljudlandskap, han ville också förbättra dem genom att belysa vikten av akustisk ekologi. Med utgångspunkt i en naturlig balans syftar man med akustisk ekologi på studiet av ljudlandskapets effekter på de som vistas i miljön (Schafer 1994/[1977]: 271). Man studerar obalanser i ljudlandskapet och vilka oönskade effekter det kan ha. Truax (1984: 57) konstaterar att begreppet är högst teoretisk eftersom det i dagens läge knappt finns orörda ljudlandskap. Att tillämpa begreppet akustisk ekologi på sport kan vid första anblicken verka långsökt men eftersom människor ska trivas i ljudlandskapet är det eftersträvansvärt att det finns en sund ekologisk balans i ljudskapandet. Tystnad kan vara ett tecken på obalans, vilket i de sportsammanhang jag studerar inte är något önskvärt.

Järviluoma konstaterar (2003: 348) att man inom ljudlandskapsforskningen inte ser ljud som enbart ett problem, det vill säga man fokuserar inte på att studera oljud, utan hur människor använder ljud. Schafer anser att människan vill skapa ljud som en påminnelse om att hon inte är ensam men han gör också skillnad på positiv och negativ tystnad (Schafer 1994/[1977]: 253-259). Enligt Roland Nilson (cit. i Aaltonen 2006: 70-71) är en definition på tystnad avsaknad av förväntade ljud och i den definitionen är också lyssnaren ständigt närvarande. Jaro använder tystnaden som något negativt i sin License 2013-kampanj9 (FFJaroTV 2012) men antyder att fansen har möjlighet att påverka föreningens framtid. Mardrömsscenariot, lagets död, symboliseras av en tyst och öde läktare.

Tystnad kan vara ett kraftigt uttrycksmedel. Johanna Nordling (2013: 20-25) beskriver i ett reportage i i tidningen Veikkaaja hur tyska fans koordinerade tolv tysta minuter som kallades Ohne Stimme keine Stimmung där man genom en samlad aktion i Tysklands två högsta fotbollsserier ville lyfta fram supportrarnas roll som stämningsskapare samt rätten att delta i diskussioner om exempelvis säkerhetsfrågor. Siffran tolv symboliserar fotbollslagens tolfte spelare, dvs. publiken. 80 ooo tysta fans på Dortmunds hemmastadion, som anses vara ett av de mest stämningsfulla stadion i världen, skapade en spöklik stämning med en hotfullt

9 Kampanjen var ett led i att lätta på FF Jaros skuldbörda. En grovt skuldsatt förening kan fråntas eller nekas licens för att spela i Veikkausliiga. http:/ /www.ffjaro.fi/license2013 
mumlande tystnad (Nordling 2013: 22). Tystnad är här tecken på obalans, att något är fel. I ishockey får arrangören inte spela musik när en spelare ligger skadad på isen. Inte heller får man spela musik när något av lagen har begärt timeout. Båda dessa är uttryck på att något inte står rätt till.

HC TPS samarbetspart Varamiespalvelu (VMP) har under säsongen 2012 köpt "tystnad" i TPS hemmahall (HC TPS 2012). Eftersom tystnad inte är något man aktivt eftersträvar är det intressant att studera syftet med tystnaden samt hur behovet av den har uppkommit. vMP:s marknadsföringschef skriver att:

\begin{abstract}
Jag har själv bekymrats av att annonsörernas reklamer under matchevenemanget inte på något sätt ökar trivseln eftersom de inte är anpassade till själva evenemanget. Vi har funderat och planerat hur man med en längre reklamtid kunde öka trivseln under matchen. Den slutliga idén att överlåta reklamtiden till TPS-anhängarna kom från dem och tillsammans utvecklade vi den intressanta helhet som vi beslöt att genomföra och sålunda överlåta vår reklamtid till fansen. (Heinonen, e-post 9.1.2013.)
\end{abstract}

Tanken med annonskampanjen är att annonsörer upplåter sin tystnad åt publiken och framförallt hejarklacken. Är detta ett tecken på en lo-fi ljudmiljö, det vill säga en miljö så mättad med information att man ser sig tvingad köpa tystnad så att de ljud som är en uppskattad del av upplevelsen ska höras? Det är i alla fall en form av manipulation av ljudlandskapet och ett tecken på att det finns för mycket oväsentligt ljud i hallen. Balansen i ljudlandskapet har manipulerats så att publiken igen ska kunna agera "naturligt". John Bale har konstaterat (1993: 141) att "fullt moderniserad" sport kommer att förändra ljudlandskapen på arenor och stadion och han är rädd att den elektroniskt förstärkta musiken kommer att öka, vilket i sin tur kommer att påverka publikens spontana sång. vMP-exemplet ovan bekräftar Bales rädsla samtidigt som man också kan ifrågasätta hur naturlig och spontan sången är då den initieras och synkroniseras på jumbotronen och med hjälp av radiotelefoner. Aktionen antar snarare karaktären av en samlad, koordinerad aktion vars bakgrund och syfte inte är uppenbar för den stora publiken.

Mängden musik har fått Stockholmslaget Djurgården Hockey (DIF) att helt lämna över ansvaret för stämningen i sin hemmaarena Hovet till supportrarna. DIF har en väldigt stark supporterkultur och man har i samråd med supporterföreningen beslutat att bygga upp stämningen på matcherna kring supportrarna. 
Genom att inte spela musik under spelavbrotten överröstas inte supportrarna av den musik som dj:n spelar. Det är en medveten strategi som har jobbats fram sedan 2005. Innan dess var det, enligt informatör Jenny Silfverstrand (i2012), väldigt NHL-inspirerat. Hos DIF är man givetvis medvetna om att det är ett väldigt sårbart att bygga upp stämningen kring supportrarna eftersom den dag gruppen inte känner för att sjunga blir det väldigt tyst $i$ hallen. DIF har alltså ingen DJ som i stunden med en mer eller mindre reaktiv handling kan förbättra stämningen i hallen. När det blir tyst så är tystnaden oåterkallelig och på det sättet liknar DIF:s strategi en återgång till en mera hi-fi ljudmiljö som till sin utformning påminner om fotbollens ljudlandskap. DIF använder nog fortsättningsvis musik som en del av spelarpresentationen och som ett element $\mathrm{i}$ ljud- ochvideoreklamen i pauserna (Silfverstrand 2013). Trots den uppenbara risken för en tystnad som man inte kan påverka genom att spela musik har stämningen i DIF:s hemmahall fått positiva kommentarer av branschfolk (DIF-BIK Karlskoga 4.1.2013).

NHL-korrespondenten Martin Palm (epost 31.10.2012) konstaterar att "Skulle man på NHL-orter överlåta musikansvaret åt fansen i hallen vore det ganska så tyst - eller rättare sagt knäpptyst. Så det där är nog en stor 'no - no' här [i NHL]. Tvärtom 'junttar' musiken på som aldrig förr, allt högre och högre." NHL har enligt Palm inga platser avsatta för hejarklackar. Det finns med andra ord inga billiga ståplatsbiljetter eller försäljning av biljetter till bortalagets supportrar. Det betyder att den typ av motsättning och kamp mellan borta- och hemmalagets supportrar som vi är vana vid i Europa inte är möjlig i NHL-hallarna runtom i Nordamerika. Många säsongskortsinnehavare har sitt kort som en investering. Enligt Palm erbjuder Vancouver Canucks därför, mot betalning, sina säsongkortsinnehavare på en service som gör service, mot betalning, som gör att man kan sälja vidare sin plats till den som betalar mest. Följden av detta är, enligt Palm, att det är möjligt att säsongkortsinnehavare kanske har helt olika människor runt omkring sig på varje match. Då uppstår ingen samhörighet och det blir omöjligt att få till stånd en hejarklacksmentalitet. För att få publiken aktiverad behövs oftast uppmanande texter på en ljustavla eller via högtalaren. Det är enligt Palm enda sättet att få ens en del att skrika "Go Canucks Go", vilket enligt hans spekulationer antagligen är det enda hejaropet som existerar. (Palm epost 31.10.2012.)

Eftersom Jaro inte har någon diskussionspartner, det vill säga någon officiell supporterförening blir föreningens vardagliga, långsiktiga publikarbete en vik- 
tig del i att försöka få till stånd en bra stämning. Storbacka medger (Storbacka \& Wargh i2012) att Jaro inte har en ljudstrategi och det handlar mera om "lösryckta tankar", som till exempel återinförandet av marschen Die Alte Kameraden som entrémusik, än en följd av medvetna val. Storbacka medger dock att man gärna skulle ha en strategi för hur man med musik ända från ca en timme innan match skulle bygga upp stämningen så att när hemmalaget kommer in "är det fest". (Storbacka \& Wargh i2012.)

Det är på intet sätt självklart att en större publik automatiskt genererar mera och bättre ljud till läktaren. I Vimpelin Veto förlitar man sig på att den talrika bobollstokiga publiken bidrar med stämningen. Bobollen är en mycket populär sport i Vindala, liksom på många andra ställen på den finländska landsbygden. För tillfället anser Kujala (i2012) att stämningen på matcherna är så pass bra att man "inte behöver förstärkningar". Man behöver med andra ord inte spela musik under matchen. Dessutom tvivlar man på att publiken skulle reagera positivt på musiken (Kujala i2012, Ojaniemi i2012). Kujala skrattar när han konstaterar att om man på Vetos matcher skulle börja spela musik när till exempel hemmalaget har slagtur skulle han nog få höra om det genast. Vimpelin Vetos val att vara återhållsam med musiken är inte bara en tradition utan också ett sätt att låta deras bobollskunniga publik få uppleva sportens ljud på dess egna villkor.

Försök att modifiera ljudlandskap handlar om att medvetet försöka förändra människors beteende. Marjamaa (i2012) nämner att publiken med sitt eget beteende har ett stort ansvar. Det gäller alltså att försöka få publiken att våga delta mera aktivt under matchen så att de med sina ljud förändrar ljudlandskapet och skapar en bra stämning. Ett nytt fenomen på idrottsarenorna har varit s.k. "piskor", det vill säga veckade pappersark, ofta sponsorerade av någon samarbetspartner. Pappersarken viks ihop mångdubbelt, och när man slår det mot till exempel sitt ben eller något annat fysiskt objekt ger det ifrån sig ett distinkt ljud med en rätt oexakt attack. Det intressanta med dessa piskor är att tröskeln att använda dem verkar vara lägre än för att klappa i händerna (mylbeee i2013, HC TPS marknadsföringskoordinator i2013). Ljudet från tusentals piskor har dock förmåganatt dominera ljudlandskapet nästan helt, vilket har gjort att HC TPS, som testade dem i en match mot Jokerit (8.12.2012 där ca 1500 Jokeritfans var på plats), varit aningen skeptiska till att använda dem på nytt. Piskorna sänker tröskeln till ljudskapande men är också är ett nytt element för kommersiella meddelanden. 


\section{Konklusioner}

Ljudlandskap är inga statiska fenomen utan skapas och formas som en levande process mellan utövarna, publiken och arrangören, det vill säga de människor som vistas i ljudlandskapet. Utgångspunkten för min studie har varit begreppen hi-fi och lo-fi enligt teorier av främst Schafer och Truax. Hi-fi och lo-fi är i de fall jag har studerat inga tydliga dikotomier och användningen av dem som sådana leder lätt till en allt för onyanserad diskussion där det ena står för något positivt och det andra för något negativ. Även lo-fi miljöer kan uppfattas som positiva förutsatt att lyssnaren med sin ljudlandskapskompetens kan skapa mening, alltså uppfatta ljuden i miljön som meningsfulla. Ishockey är Finlands populäraste sport, trots att den lo-fi miljö som präglar ishallarna inte nödvändigtvis tilltalar alla människor. En hi-fi fotbollsmiljö där man hör ljud från utövarna klart och tydligt är, i motsats till tennis (se Wertheim 2002), inte heller något eftersträvansvärt.

Mina observationer är gjorda främst ur ett hemmalagsperspektiv. Ur det perspektivet är tystnad ofta synonymt med tomma läktare, förlust och/eller dålig stämning. Ur en bortasupporters synvinkel kan det givetvis ge stor tillfredställelse att uppleva en tyst hemmapublik. Tystnad är något man i denna kontext vill undvika och kan anses vara symptom på en ljudmiljö i obalans. Trots att ljuden kan vara intressanta att höra är en hi-fi ljudmiljö, med enbart utövarljud, i de här sportkontexterna inte eftersträvansvärda. Därför har man med olika strategier förändrat och designat ljudlandskapet för att korrigera den obalans som tystnaden är ett uttryck för. Vanligtvis förbättras ljudlandskap med inspelad musik när man upplever att de ljud som skapas av människorna som vistas i miljön inte möter arrangörens förväntningar. Syftet är att höja trivseln och underhållningsvärdet. Inom ishockeykulturen har till exempel användningen av musik i spelavbrott blivit mer eller mindre norm.

Traditioner för hanteringen av ljud, musik och reklamer har format en kultur på lokalnivå. Ljudlandskapet på ett sportevenemang kan tolkas som ett akustiskt samhälle och ett system inom vilket akustisk information utbyts. Individens unika ljudlandskapskompetens blir en oundviklig resurs i de fall där ljudlandskapen blir väldigt komplexa. På en högre abstraktionsnivå existerar också ett akustiskt samhälle som innefattar hela bobolls- respektive fotbolls- och ishockeysamhället. Denna kompetens ger den väldigt aktive sportkonsumenten möjlighet att inte 
bara notera skillnader på lokalnivå utan också notera hur ljudmiljön i exempelvis ishockeysamhället förändras.

Det vore aningen förhastat att beskriva musikanvändning inom bobollen som schaferskt teknikkonservativ utgående från studier av bara ett lag ${ }^{10}$. Man kan dock konstatera att Vimpelin Vetos ljudlandskap under matchen är medvetet hi-fi i jämförelse med ishockeylaget TPs. Med hi-fi syftar jag här på publikens möjligheter att delta i skapandet av ljudlandskapet utan att behöva bryta sig igenom elektroniskt förstärkta och reproducerade ljud. Ljudmiljön formas under pågående match främst av publikens reaktioner på idrottsutövarnas prestationer. Arrangören försöker inte nämnvärt påverka relationen mellan publiken och idrottsutövarna, även om den har tillgång till teknik som möjliggör transfoni. Vimpelin Vetos val att vara återhållsam med musik inuti i matchen är också en direkt respons på den bobollskultur som finns i byn. Bobollssäsongens symbios med den finska naturen, men också föreningens samhälleliga ansvar, bidrar till att publiken vill ha en bobollsupplevelse på bobollens villkor, utan inflytande av musikaliska förstärkningar.

Ishockey är den mest kommersiellt exploaterade sporten och har även den mest komplexa ljudmiljön. Den moderna ishockeyupplevelsen har mycket av tv-soffans bekvämligheter. Inom ishockeykulturen ifrågasätts inte användning av musik och musik genomsyrar sporten även på amatörnivå. Det finns dock tendenser att ishockeyns ljudmiljö börjar innehålla en så stor mängd information att det uppstår obalans i ljudlandskapet, vilket till och med kan passivera publiken. Om publiken inte interagerar med musiken förklaras det ofta genom att kritisera valet av musik. I detta sammanhang är det viktigt att lyfta fram att, utgående från mitt fältarbete, verkar det det bara finnas ett fåtal låtar som verkligenengagerar HC TPS-publiken, exempelvis redan tidigare nämnda Tepsi Tekee Kohta Maalin. Trots att musiken bidrar till en mera lo-fi ljudmiljö interagerar publiken med musiken eftersom de med sin ljudlanskapskompetens och relation till laget bedömer musiken som meningsfull i just den situationen.

Viljan att interagera och skapa ett gemensamt ljudlandskap tillsammans med den transfona musiken verkar inte delas av alla ishockeybesökare. Därför blir dj:ns roll att välja ut meningsfull musik för evenemanget viktig. Men målet att

10 I herrarnas Superpesis fanns det många lag som säsongerna 2012 och 2013 använde rikligt med musik, t.ex. Sotkamon Jymy och Koskenkorvan Urheilijat. 
också med reklamer nå ut till en bred publik gör att mängden ljudhändelser ökar. Det schizofona i situationen är inte möjligheten att använda teknik för att transportera ljud från en annan tid och plats utan snarare det faktum att musiken, som kanske är ämnad att fungera positivt genom att förbättra publikens trivsel och skapa en bättre stämning, i verkligheten också lägger sordin på en del av publikens spontana engagemang och ljud. Det finns en risk att publiken inte bara reagerar negativt på att man spelar musik, utan också på den musik som spelas.

En "återgång" till en mera osyntetisk ljudmiljö med europeisk supporterkultur som förebild är i HC TPs fall inte helt realistisk, åtminstone inte så länge hallen är halvtom. Att låta bli att använda all teknisk apparatur som den moderna arenan erbjuder skulle kanske också upplevas konstlat. Den tidigare nämnda annonstystnaden med överenskomna ritualer är snarare en bekräftelse på en lo-fi ljudmiljö än ett genuint överlåtande av ansvaret för ljudskapandet till publiken. Att hejarklackar har en viktig roll som ljud- och stämningsskapare i finska ishallar samtidigt som en stor mängd av stämningshöjande musik överlappar hejarklacksverksamheten är i detta hänseende en paradox ${ }^{11}$.

Den finska fotbollen lider av att publiken inte alltid för ljud på matcherna trots att möjlighet att göra sig hörd är bättre än i ishockey. Jaro hoppas att det samhällsansvar man försöker ta även ska ses och höras som ett publikt engagemang på läktarplats. Kulturen inom fotboll är dock sådan att även en betydligt mindre mängd information som försöker föra bort fokus från händelserna på planen kan uppfattas som ett brott mot normen. Detta eftersom fotboll väldigt starkt förknippas med hejarklackar och läktarsång, alltså den enskilda individens möjligheter att uttrycka sin identitet kollektivt. Om och när hejarklackarna tystnar har kanske Bale och Oriards profetior gått i uppfyllelse och upplevelsen av sport har blivit en passiv konsumtion som påminner om tv-tittande. Den sociala upplevelsen, att ta del av något tillsammans, är trots allt det som drar människor till arenorna (Marjamaa i2012, Ojaniemi i2012). Människor, tillsammans, skapar läktarkulturen och ljudlandskapet. Ett ensidigt ljudskapande från arrangörshåll kan i förlängningen ses som en reaktiv inställning till publikens upplevda passivitet. Även arrangörer behöver ljudlandskapskompetens för att avgöra vilken sorts ljudkultur som uppskattas och hur man med sitt eget agerande kan föda

11 I detta hänseende ska det bli intressant att följa med hur ishockeyföreningens Jokerits planerade flytt till ryska KHL-ligan förändrar det akustiska samhället kring laget och dess matcher. 
och göda publikt engagemang. Avsaknad av engagemang kan vara ett tecken på bristande intresse eller för lite publik. Då kan utmaningen att proaktivt återställa den komplexa ekologin vara betydligt mera komplicerad än att byta låt eller skruva upp volymen. 


\section{Källförteckning}

Aaltonen, Maria (2006) "Tystnadens ljudlandskap". Sata suomalaista ä̈nimaisemaa. Red. Helmi Järviluoma \& Ari Koivumäki, Meri Kytö \& Heikki Uimonen. Helsingfors: sKs.

Anttila, Anu-Hanna (2001) "'Hunajata, hunajata.' тps:n suuri yleisö. Jääkiekkoilta Turussa.

Red. Anu-Hanna Anttila \& Hannu Ruonavaara. Turku: Kirja Aurora \& Turun yliopiston sosiologian laitos. ss. 78-109.

Asposalo, Lari \& Kuosmanen, Johanna \& Rantanen, Elina \& Takala, Kerttu (2001) "Se on kakkonen nuija!" Jääkiekkoilta Turussa. Red. Anu-Hanna Anttila \& Hannu Ruonavaara. Turku: Kirja Aurora \& Turun yliopiston sosiologian laitos. ss. 78-109.

Back, Les (2003) "Sounds in the Crowd". The Auditory Culture Reader. Red. Michael Bull \& Les Back. Oxford: Berg. Ss. 311-327.

Bale, John (1994) Landscapes of modern sport. Leicester: Leicester University Press

FFJaroTv (2012) License 2013. <http:/ / www.youtube.com/watch?v=sqLQmfuhspw\&list=uUGno wMfp-uG8j3NonbO4Qgg\&index=7>_(läst 25.10.2012)

HC тPS (2012) "vмP Group luovutti oman mainosaikansa tPs:n kannattajille". hc.tps.fi $<$ http:/ /hc.tps.fi/uutiset-ajankohtaista-vmp_group_luovutti_oman_mainosaikansa_tpsn_ kannattajille $\geq$ (läst 26.10.2012)

Ipsen, Detlev (2002) "The Urban Nightingale - or some theoretical considerations about sound and noise". Soundscape Studies and Methods. Red. Helmi Järviluoma \& Gregg Wagstaff. Helsinki: Finnish Society for Ethnomusicology

Järviluoma, Helmi \& Koivumäki, Ari \& Kytö, Meri \& Uimonen, Heikki (2006) Sata suomalaista äänimaisemaa. Helsingfors: Suomalaisen Kirjallisuuden Seuran Toimituksia.

Järviluoma, Helmi \& Kytö, Meri \&, Truax, Barry, Uimonen, Heikki \& Vikman, Noora (2009) Acoustic Environments in Chance \& Five Village Soundscapes. Tampere: Tampere University of Applied Sciences \& University of Joensuu.

Kassabian, Anahid (1999) "Popular". Key terms in popular music and culture. Red. Bruce Horner \& Thomas Swiss. Oxford: Blackwell Publishers Ltd

Kytö, Meri (2011) "We are the rebellious voice of the terraces, we are Carsi: constructing a football supporter group through sound" Soccer and Society, 1/2011, ss. 77-93.

Laitinen, Erkki (1983) Pesäpallo - kansallispeli 60 vuotta. Suomen Pesäpalloliitto.

McCartney, Andra (2010) "Ethical questions about working with soundscapes". soundwalkinginteractions.wordpress.com, <http:/ / soundwalkinginteractions.wordpress. com/2010/o6/24/ethical-questions-about-working-with-soundscapes / >(Läst 16.07.2013 
Nagböl, Sören \& Bale, John (1994) A View of English Football: Sport and Sence of Place. Jyväskylän yliopiston yhteiskuntapolitiikan laitoksen työpapereita no 851994

Nordling, Johanna (2013) Väkivallan uhka. Veikkaaja 3/2013.

Oriard, Michael (1981) Professional football as cultural myth. Journal of American Culture 3/1981, ss. $27-41$.

Pärnänen, Antti (2012) Kaunis peli. Veikkaaja 41/2012. Ss. 14-19

Rowe, David (1995) Popular Cultures: Rock Music, Sport and the Politics of Pleasure. London: Sage.

Rowe, David (2003) Sport, Culture and the Media: the Unruly Trinity. Berkshire: McGrawHill Education.

Schafer, R. Murray (1994/[1977]) The Tuning of the World. Vermont: Destiny Books

Suomen Jääkiekkoliitto ry., (2011) Jä̈̈kiekon sä̈̈nnöt 2010-2014. Unıpress Suomi

Suomi24 diskussionforum (2008) "Kantelu Sotkamon järjestyksenpidosta". keskustelu.suomi24.fi, <http:/ / keskustelu.suomi24.fi/node/6212586> (läst 5.10.2012)

Superpesis (2012) Katsojamäärät 2012 http:/ /www.pesis.fi/@Bin/2859930/

katsojamaarat+2012+M.pdf (läst 1.11.2012)

Stockfelt, Ola (1988) Musik som lyssnandets konst. Skrifter från Musikvetenskapliga institutionen, Göteborg: 18.

Stockfelt Ola (1994) “Cars, Buildings, Soundscapes." Soundscapes. Essays on vroom and moo.

Red. Helmi Järviluoma. Tampere: University of Tampere, Department of Folk Tradition, Publications 19.

Truax, Barry (1984) Acoustic Communication. Ablex Publishing Corporation.

Uimonen, Heikki (2005) Ä̈̈ntä kohti. Ä̈̈niympäristön kuuntelu, muutos ja merkitys. Acta

Universitatis Tamperensis 1110. Tampere: Tampere University Press.

Uimonen, Heikki (2011) Tarkkaile ympäristöäsi! Kuuntelukävelyt ja äänittäminen äänimaiseman laadullisen arvioinnin välineinä. Yhdyskuntasuunnittelu 1/2011, ss. 44-58.

Tuovinen, Petri (2007) "Fanilaulut jalkapallokannattajien identiteetin rakentajana". Musiikki, 3/2007, ss. 7-32.

Valkonen, Eero (1997) Kuka kontrolloi peliä? Hämeenlinna: Karisto Oy.

Wertheim, Jon (2002) "The quiet sounds of tennis". sportsillustrated.cnn.com, <http:/ / sportsillustrated.cnn.com/inside_game/jon_wertheim/news/2002/o1/14/wertheim_ viewpoint/> (Läst (3.3.2013)

Wikipedia (2013) "Vimpeli" http:/ / fi.wikipedia.org/wiki/Vimpeli(läst 10.1.2013)

Wrightson, Kendall (2000) "An Introduction to Acoustic Ecology". Soundscape, 1/2000, ss. 10-13. 


\section{Otryckta källor:}

Veikkausliigan ottelumanuaali 2012. Veikkausliiga.

Materialet finns i forskarens förvar

Ottelujuontajan kansio 2012. Superpesis.

Materialet finns i forskarens förvar

\section{E-post}

Heinonen, Ville 2013. VMP:n mainos HC TPs:n otteluissa. 9.1.2013

Palm, Martin 2008. Re: Ishockeymusik. 28.1.2008.

Palm, Martin 2012. Re: Old Time Hockey 31.10.2012

\section{TV-sändningar}

Djurgårdens IF - Asplöven 21.10.2012 (Viasat Hockey)

Djurgårdens IF - BIK Karlskoga 4.1.2013 (Viasat Hockey)

HC TPS - Jokerit 8.12.2012 (Urhotv)

\section{Intervjuer}

HC TPS Marknadsföringskoordinator (i2013) Åbo 10.1.2013. Intervjuare Kaj Ahlsved. Intervjun finns i forskarens förvar.

HC TPS DJ mylbeee (i2013) Åbo 9.1.2013. Intervjuare Kaj Ahlsved. Intervjun finns i forskarens förvar.

Heikkinen, Jarmo (i2012) E-postintervju. Intervjuare Kaj Ahlsved. Frågorna sända 4.9.2012. Svar 5.9.2012. Intervjun finns i forskarens förvar.

Kujala, Jukka-Pekka (i2012) Vimpeli 11.12.2012. Intervjuare Kaj Ahlsved. Intervjun finns i forskarens förvar.

Lundström, Peter (i2012) Helsingfors 4.12.2012. Intervjuare Kaj Ahlsved. Intervjun finns i forskarens förvar. 
Marjamaa, Timo (i2012) Helsingfors 14.11.2012. Intervjuare Kaj Ahlsved. Intervjun finns i forskarens förvar.

Ojaniemi, Arto (i2012) Helsingfors 14.11.2012. Intervjuare Kaj Ahlsved. Intervjun finns i forskarens förvar.

Silfverstrand, Jenny (i2013) Telefonintervju 14.12.2012. Intervjuare Kaj Ahlsved. Frågor skickade per e-mail 11.12.2013. Svar som telefonintervju 14.12.2012. Sammandrag av intervjun finns i forskarens förvar.

Storbacka, Nicklas \& Wargh, Jimmy (i2012) Jakobstad 7.10.2012. Intervjuare Kaj Ahlsved.

Intervjun finns i forskarens förvar

Viitanen, Iku (i2008) Åbo 7.2.2008. Intervjuare Kaj Ahlsved.

Intervjun förvaras i Sibeliusmuseums arkiv Sm Fält 0005 .

\section{Fältarbetsprotokoll och dagbok}

Ahlsved, Kaj 2012a Vimpeli-Kitee 11.8.2012

Ahlsved, Kaj 2012b Vimpeli-Joensuu 21.8.2012

Ahlsved, Kaj 2012C Vimpeli-Sotkamo 2.9.2012

Ahlsved, Kaj 2012d TPS-HPK 13.9.2012

Ahlsved, Kaj 2012e FF Jaro-FC Lahti 7.10.2012

Ahlsved, Kaj 2012f TPS-Ilves 25.10.2012

Ahlsved, Kaj 2013 TPS-Ilves 8.1.2013 